\title{
Strengthening Indonesian Banking Industry to Comply with ASEAN Banking Integration Framework Concerning Reciprocity and Gap-Reduction Principles
}

\author{
Tri Handayani ${ }^{*}$, Lastuti Abubakar ${ }^{* *}$, Supraba Sekarwati $\mathbf{W}^{* * *}$, Ida Nurlinda*** \\ DOI: https://doi.org/10.22304/pjih.v5n2.a5
}

Submitted: January 22, 2018 | Accepted: August 31, 2018

\begin{abstract}
Indonesia maintains the commitment to strengthen economic growth and to promote financial stability in the ASEAN region. However, the differences of the economic growth among the ASEAN members become an obstacle for the ASEAN Banking Integration Framework (ABIF). The ABIF promotes the gap-reduction to enhance the ASEAN members' capacity to get benefits from the integration framework. However, some countries make some exceptions for the ABIF agenda. One of the benefits of ABIF is that Indonesia Banks can have access to broader market. To get the access, Indonesia has to fulfill as Qualified ASEAN Banks (QABs). One of the criteria is sufficient capital of banks. QABs requires bilateral agreement between state parties and promote the reciprocity and gap reduction principles. For instance, according to a schedule of specific commitment for banking sector, Indonesia and Malaysia had launched commercial presence on July 2017. One of the Indonesian Bank that comply with the criteria of QABs is PT. Bank Mandiri (Persero). It has established a branch office in Malaysia by the end of 2017. Thus, it proves that the Indonesian banking industry is ready to compete in the ASEAN Market
\end{abstract}

Keywords: ASEAN Banking Integration Framework (ABIF), banking law, qualified ASEAN Banks.

\section{Penguatan Sektor Industri Perbankan Indonesia dalam ASEAN Banking Integration Framework berdasarkan Prinsip Timbal Balik yang Seimbang dan Pengurangan Ketimpangan}

\begin{abstract}
Abstrak
Indonesia berkomitmen untuk tetap memperkuat pertumbuhan ekonomi dan meningkatkan stabilitas keuangan di wilayah ASEAN. Namun demikian, perbedaan pertumbuhan ekonomi diantara Negara-negara anggota ASEAN menjadi hambatan terlaksananya ASEAN Banking Integration Framework (ABIF). ABIF pada dasarnya dibentuk dengan tujuan untuk mengurangi kesenjangan dan meningkatkan kapasitas Negara-negara anggota ASEAN sehingga mendapatkan manfaat dari ABIF, walaupun beberapa negara masih dikecualikan

PADJADJARAN Journal of Law Volume 5 Number 2 Year 2018 [ISSN 2460-1543] [e-ISSN 2442-9325]

* Lecturer in Faculty of Law, Universitas Padjadjaran, Jalan Dipatiukur Nomor 35 Bandung, tri.handayani@unpad. ac.id, S.H., M.H. (Universitas Padjadjaran).

** Lecturer in Faculty of Law, Universitas Padjadjaran, Jalan Dipatiukur Nomor 35 Bandung, lastuti62abubakar@ gmail.com, S.H., M.H., Dr. (Universitas Padjadjaran).

*** Lecturer in Faculty of Law, Universitas Padjadjaran, Jalan Dipatiukur Nomor 35 Bandung, supraba@unpad.ac.id, S.H., C.N., Dr. (Universitas Padjadjaran).

**** Lecturer in Faculty of Law, Universitas Padjadjaran, Jalan Dipatiukur Nomor 35 Bandung, ida.nurlinda@unpad. ac.id, S.H. (Universitas Padjadjaran), M.H., Dr. (Universitas Gadjah Mada).
\end{abstract}


dari beberapa agenda yang disepakati dalam ABIF. Pelaksanaan ABIF didasarkan pada perjanjian bilateral. Berdasarkan schedule of specific commitment Indonesia dan Malaysia meluncurkan kegiatan komersial banking pada July 2017. Salah satu Bank dari Indonesia yang memenuhi kriteria QABs adalah PT. Bank Mandiri (Persero) dan akan mengoperasikan kantor cabang penuh di Malaysia pada akhir 2017. Dengan demikian, merupakan suatu bukti bahwa industri perbankan Indonesia sudah siap menghadapi persaingan di Pasar ASEAN.

Kata kunci: ASEAN Banking Integration Framework (ABIF), bank-bank ASEAN yang berkualitas, hukum perbankan.

\section{A. Introduction}

1. The Development of Indonesia Banking Sector

Banking covers anything related to bank; it includes institutions, business activities, and ways and processes in carrying out bank business activities. ${ }^{1}$ Indonesian Banking is carried out its function based on economic democracy and prudential banking principles. The main function of banking is to collect and manage public funds. It aims to support the implementation of national development in order to improve equity, economic growth, and national stability towards the improvement of people's welfare. Banking is a means to maintain the continuity of the implementation of national development, as well as to realize a just and prosperous Indonesian society based on Pancasila and the 1945 Constitution.

Indonesian Banking Roadmap 2015-2019 explains that the development of conventional bank is intended to make Indonesian banks able to work in harmony with the Indonesian development vision, which is to enable to become Indonesia self-reliant, advanced, fair, and prosperous. The direction of development and strengthening of the Indonesian banking industry is designed to anticipate challenges in the banking industry, both in domestic and global scales. ${ }^{2}$ On the domestic level, Indonesia is one of potential countries that is able to support the financial services, including the banking industry. On the other hand, on the regional level, Indonesia has the potential to be developed through the existence of ASEAN Economic Community (AEC). Within the framework of AEC, the ASEAN Banking Integration Framework (ABIF) exists. Indonesia and Malaysia are the prominent countries that lead the ABIF initiative.

The scientific theory of behavior economic provides a useful normative standard to evaluate law and policy. Law is not just technical arguments. It is an instrument to achieve important social goals. ${ }^{3}$ The rapid development of the international economy gives impacts on national economies, especially on national banks in carrying out their functions. Therefore, the government sees the need to reform

Article 1 of the Law Number 7 of 1992 as Amended by the Law Number 10 of 1998 on Banking.

Indonesia Financial Services Authority (Otoritas Jasa Keuangan Indonesia), Indonesian Financial Services Sector Master Plan 2015-2019: Fostering growth and Addressing Challenges in the Financial Services Sector, Today and Tomorrow, Jakarta: Indonesia Financial Service Authority, 2016, p. 14.

3 Robert Cutter and Thomas Ulen, Law \& Economics, New York: Addison Wesley, 2000, p. 3. 
the banking law to enable the national banks to expand their operational services, such as expanding service coverage, strengthening capital assets, etc. Indonesian banking sector needs to strengthen assets and capital to be competitive in the international market. A healthy bank capital refers to the Basel III framework that is adopted and is set forth in the Regulation of Bank Indonesia and Financial Services. The Indonesian banking sector development should be aligned with the direction of the international regulation to maintain financial system stability. Consequently, the authority is obliged to strengthen bank capital level, as mandated in the Law Number 9 of 2016 Concerning Prevention and Handling Financial System Crisis. This law requires every bank to have a stable financial statement, such as the availability of bail-in debt, and the net stable funding ratio to create a healthy and stable banking system. The high cost of crisis resolution has made the regulator restricts the State Budget Expenditures. Hence the mitigation of problems encountered by a Bank prioritizes the use of resources of the respective Bank without using state budget. Thus, the strengthening of bank capital structure through the expansion of bank business activities is very important. In addition to interest, banks can get profit from other activities that provide margin-based and fee-based benefits. If the Indonesian banking industry was healthy, it would have a strong capital. It may open opportunities to increase market access both in regional and international levels. This is also a part of the preparation of the ABIF implementation, which will be fully implemented in 2025.

\section{Implementation of ASEAN Banking Integration Framework (ABIF) In Indonesia}

The ABIF is a part of ASEAN Economy Community that significantly affect Indonesian banking. The Indonesian banking needs to implement the ABIF to get positive impacts, such as operational expansion in partner countries, service quality improvement, and increase of trade and investment transactions in ASEAN region. The banking integration needs four steps before its implementation. The first is the capacity and competency development of individual and institution. The second is harmonization of banking regulation among countries, no less than the same definition and standards. The third is to build financial infrastructure. The fourth is the preparation of Indonesian banking to fulfill Qualified ASEAN Banks criteria.

The ABIF Framework has three main objectives: (1) facilitating the entry of foreign banks; (2) eliminating discrimination against foreign banks; and (3) simplifying banking regulations in the ASEAN region. Within this framework, banks with "ASEAN quality banks" (QAB) status will be allowed to sign reciprocal bilateral agreements to operate freely in neighboring countries and to receive equal treatment to local banks. This goal is based on ASEAN principles: inclusiveness, transparency, and reciprocity. Therefore, to ensure that these principles, it is necessary to have a strong and integrated banking sector supervision, which is complemented with effective supervision arrangements. 
The banking regulation and supervision aims to optimize the functions of Indonesian banking industry to create a sound banking system. Therefore, the banking law can be reformed by adopting some international standards. The purpose of international standards adoption is to strengthen and structure financial services institution. The adoption aims ${ }^{4}$

(1) to structure financial ownership to support sustainable economic development;

(2) to strengthen the application of international practices to financial service sector regulations, reports, and supervisions;

(3) to develop governance and risk management in line with best practices;

(4) to strengthen preparation towards ASEAN financial market integration;

(5) to formulate effective regulations to create fair competition and to prevent regulatory arbitrage;

(6) to regulate remuneration for actors of financial services sector; and

(7) to improve efficiency and stabilization in the financial services sector.

Responding to these conditions in facing the AEC, the regulator needs to coordinate more strongly across sectors, not only to focus on banks. It needs to look at the conditions of other financial industries and the real sectors. Therefore, Indonesia needs a framework that regulates cross-sectoral activities. The reciprocal principle of the ABIF is one of the important principles of the ABIF, where market access and operational flexibility are acceptable and mutually beneficial for the ASEAN members. Under the ABIF, a prospective QAB needs to meet the prudential requirement of ASEAN members to enter and to operate in a host country. $A$ country's readiness is the first influencing factor in considering the participation of ASEAN members in the ABIF. To start the process of ABIF implementation, the ASEAN central bank and the financial supervisory authority should formulate multilateral ABIF guidelines. This should be followed by bilateral agreements regarding the entrance of banks into other ASEAN members.

According to Basel III, Indonesian Financial Services Authority (OJK) requires all commercial Banks categorized as Book IV to meet a Minimum Liquidity Coverage Ratio $100 \%$ by the end of 2018 . It is Indonesian commitment to implement international standards. The implementation of Basel III starts with Banks categorized as Book IV (The Banks with core capital for minimum Rp30 Trillion). These banks have major impacts to the whole banking industry. The global financial crisis in 2008 showed that even the sufficient capitalization is not enough to face the crisis. The banks must have enough liquidity to solve the crisis. Thus, a certain standards of minimum liquidity level are required and must be maintained to anticipate crisis. In 2017, the OJK regulated liquidity level by the Regulation of OJK Number 50/POJK.03/2017 concerning The Obligation of Net Stable Funding Ratio. This regulation is a stage to create a national sound banking system that is able to develop both in national and international levels. Basel implementation is very important for the Indonesian

Indonesian Financial Services Authority (Otoritas Jasa Keuangan Indonesia), Op.cit., p. 57. 
banking sector because it requires banks to have sufficient capital to meet all obligation and to cope with unpredictable shocks that may arise in the future. Moreover, Basel implementation is very important to support the banking objectives to increase its competitiveness in facing the ABIF 2020. The ABIF 2020 requires the compliance of the Basel implementation as a requirement to be Qualified ASEAN Banks.

The multilateral framework of principles and rules for trade and services is established to expand trade under transparency and progressive liberalization and to promote the economic growth of all trading partners. The progress of developing countries will increase the ASEAN economy. The interconnectedness of ASEAN financial system requires regulatory frameworks to support regional financial stability, such as the obligation for stable funding and sufficient capitals. The ASEAN members have signed the ASEAN Framework Agreement on Services (AFAS) in 1995. The AFAS aims to enhance cooperation in services that substantially eliminate restriction to trade and services among ASEAN members. The General Agreement on Trade in Services (GATS) undertook this liberalization. The decisions of the ASEAN leaders to establish the ASEAN Community, including ASEAN Economic Community (AEC), was made in the declaration of ASEAN concord II. It was adopted on 7 October 2003 in Indonesia. The AEC Blueprint was signed in 2007 to transform ASEAN into a single market and production base, a highly competitive economic region, a region of equitable economic development, and a region which is fully integrated into the global economy. The Adoption of 2007 ASEAN Charter and the agreements of the AEC transformed ASEAN into an internal governmental institution and accelerated the emergence of ASEAN Law. ${ }^{5}$ The implementation of a single market and production base will direct ASEAN members to the five core elements that cover the free flows of (1) goods, (2) services, (3) investment (4) capital, and (5) skilled labors. These will lead to a transformation in the way of business activities in ASEAN region. Therefore, there is a need to consider the logistics and supply chain system, either in general and specific, for each ASEAN member. ${ }^{6}$

Amid the diversity of economic and social backgrounds, a well prepared and organized integration process needs the member states to maintain financial sector development and socio-economic stability. By this spirit, the following principles guide the ASEAN members in handling their financial liberalization. ${ }^{7}$

Pasha L Hsieh, "Examining The Liberalization of ASEAN's Legal Services Market: Challenges and Reforms", http://www.cnplaw.com/en/interlaw/files/submission Hsieh.pdf, accessed on June 2018.

6 Mahendrawathi ER (et.al.), "Readiness of Indonesian Companies for ASEAN Economic Community (AEC)Preliminary Findings from Automotive and Garment Industry", paper presented on the Proceeding of 2014 International Conference on Industrial Engineering and Operations Management, Bali-Indonesia, January 7-9, 2014.

7 Park Yung Chul, The Road to ASEAN Financial Integration: A Combined Study on Assessing the Financial Landscape and Formulating Milestone for Monetary and Financial Integration in ASEAN, Philippines: ASEAN Development Bank, 2013, p. 6. 
1. The liberalization is performed through the "ASEAN minus X" formula. The members that are ready to liberalize can do it first and be joined by others later.

2. The members pay respect for national policy objectives and differences in the level of economic and financial sector development.

3. The members must be flexible in setting their own preconditions for liberalization and establishing their own timelines.

4. The members adhere the internationally recognized standards of financial regulation.

5. The members adopt adequate safeguards against macroeconomic instability and systemic risks that could arise from the liberalization process, including the right to uphold the regulatory discretion of the national authorities in taking the necessary measures.

Indonesia maintains the commitment to strengthen economic growth and to promote financial stability in the ASEAN region. This is an effort to foster sustainable and inclusive growth. The AEC goals are stated in the roadmap for monetary and financial integration of ASEAN. It is intended to be a smoothly functioning regional financial system with more liberalized capital account regimes and interconnectedness with capital market. It is expected to facilitate greater trade and investment flows in the region.

Financial integration and the growth of regional banks give rise to the potential of financial instability across borders. The regulatory frameworks have developed internationally to minimize the effect of financial contagion. They cover frameworks that facilitate the resolution to restructure or to wind up the distressed financial institutions. International experiences reveal the inherent difficulties of crossborder cooperation, particularly in time of crisis. Cross-borders cooperation refers to cooperation between authorities in home and host countries. ${ }^{8}$

Financial integration has many economic benefits but it also carries potential risks. The financial sector still dominated by banks and the banking sector is the key driver in the financial integration process. The ASEAN banking Integration Framework (ABIF) is an initiative of ASEAN leaders on banking under the AEC framework. The $A B I F$ aims to provide financial stability in the region and to achieve multilateral liberalization in the banking sector by 2020 for ASEAN commercial banks. The ASEAN members currently are in the diversity of financial market development, economic, structure, and priorities. ${ }^{9}$

Indonesia and Malaysia are two ASEAN members that lead the initiative of ABIF. The ASEAN banking integration Framework (ABIF) is a tool to provide greater market access and operational flexibility for Qualified ASEAN Banks and to encourage the Qualified ASEAN banks to have a greater role in facilitating trade and investment

\footnotetext{
Vivien Chen, et.al., "Cross Border Cooperation in Bank Resolution: A Framework For ASIA", Singapore Journal of Legal Studies, 2016, p. 2.

9 Maria Monica Wihardja, “Financial Integration Challenges in ASEAN Beyond 2015”, Economic Research Institute for ASEAN and East Asia, 2014, p. 8.
} 
in ASEAN region. Stronger regional banks provide improved banking services to corporates and facilitate trade and investment contributing to the improvement of the region's economic activity. In particular, small and medium size enterprises (SMEs), an important employer class, will benefit from the greater access. Improved financing services could include more infrastructures financing, especially for Greenfield projects, which will also help to boost economic development in ASEAN. It is not easy to create a framework that can accommodate the interests of ten countries to achieve banking integration. In addition to considering the direction of future financial sector policy, the ABIF must be able to accommodate the existing cross border banking relationship between ASEAN members.

ABIF is a part of ASEAN Financial Agreement Service (AFAS) and Financial Services Liberalization (FSL). In the ABIF implementation, the Indonesian government must prioritize national interests. The banking sector needs to expand abroad and will be escort by the OJK through the ABIF. This can be done by negotiations on enactment of bilateral agreements with the banking authorities of other ASEAN members. This bilateral agreement enables Indonesia to send selected banks as Qualified ASEAN Banks (QABs). Subsequently, they will obtain approval to enter the market of other ASEAN members. The agreement between Bank Indonesia, Financial Services Authority, and Bank of Malaysia has been signed. It is important to assure that the ABIF can be implemented despite the mutual benefits. The ABIF has several principles of reciprocity and gap reduction. the reciprocity principle is an effort to prioritize the gap reduction. The principle of gap reduction is an effort that underlies the agreement.

The ABIF had been initiated with the spirit to accelerate ASEAN banking integration process while preserving regional financial stability. It has set basis for ASEAN members to enter reciprocal bilateral agreement to provide Qualified ASEAN Banks (QABs) with greater market access and operational flexibilities. The ability to provide banking services in the territory of ASEAN members with the removal of limitations or restriction to market access. The QABs will be granted similar treatment to the bank of host country. Operational flexibility refers to areas covering the scope of activities, the supply of product and services, and other flexibilities that have been agreed mutually between the parties. The reciprocal agreement is the level of concession that will be negotiated between participating states based on reciprocity. It means that the arrangement between two or more ASEAN members should be mutually beneficial and acceptable to the involved parties. ${ }^{10}$

The purpose of ASEAN Banking Integration Framework (ABIF) is to enable regional banks to compete on the same level as local banks in a host country. The ABIF Bank participants should meet a set of criteria of QABs. The criteria include (1) well managed, (2) having sufficient capital, (3) gaining a recommendation from the

10 Yati Kurniati, "ASEAN Banking Integration Framework; Advance and Challenge in Regional Integration Jointly Organized by Hitosubashi University and the IMF Regional Offices for ASIA and the Pasific", Macroprudential Policy Department of Bank Indonesia, 2016, p. 11. 
authority, (4) meeting the Basel provisions, and (5) considered as important banks in the country of origin. ${ }^{11}$ The ASEAN still faces challenges of a sizeable gap between ASEAN members. The ABIF had promoted to reduce the gap and to enhance readiness of ASEAN members to participate through capacity building so that all members can have full benefits of the integration.

The legal issues are discussed in this article are (1) the availability of Indonesia regulations to comply with international or regional standards and (2) the urgency to create cooperation among Indonesia Financial Services Authorities with the other related institution in the implementation of ABIF. These issues require comprehensive and integrative mapping and study. It cannot only provide certainty guarantee of legal protection but it should be able to make ABIF opportunities for the greatest prosperity of society and national economic development.

This study employed theoretical legal method and descriptive approach. The data collection was performed by primary and secondary sources. The primary sources are ASEAN Agreement on Services and Banking Regulation, which is related to ASEAN Banking Integration Framework. The secondary sources are law journals, articles, and textbooks. The study was guided with the collection of materials. Since academic legal research can be purely descriptive, it generally includes normative standpoints and description of law from the point of view of achieving a particular aim. This study used international sources (conventions) and any related documents such as international commentaries. It refers to documents from ASEAN Protocol the sixth Package of Commitments on Financial Services under The ASEAN Framework Agreement on Services. The literature study was focused to examine the ABIF, which will affect to the readiness of the legal infrastructure of Indonesian banking law. In addition, this study also performed economic law analysis that complements the results of legal research to obtain results that are more comprehensive. In economic point of view, this method is causality study. It aims to find an explanation of a symptom's occurrence. It focused on the effect of the enhancement of banking law to the obligation for every bank to have a sufficient capital and to optimize the market access and operational flexibility for Qualified ASEAN Banks.

\section{ASEAN Banking Integration Framework (ABIF) as the Regional Financial Integration for Greater Access of Banking}

The global financial crisis makes the financial integration to become an important agenda. The integration enables Indonesia banks to have an opportunity to participate actively in enhancing regional cooperation among ASEAN members. The ABIF is an opportunity for Indonesia to develop national banking business to compete in the ASEAN free market.

1 Suparman Zen Kemu, "The Readiness of Indonesia's Banks Facing ASEAN Community (AEC)", Information Management and Business Review, Vol. 9, Issue 3, p. 19. 
ABIF aims to strengthen and to harmonize banking standards for further deepening regional financial integration. The ABIF is designed to actualize ASEAN Banks for the entrance and the operation in in other ASEAN members. In addition, the ABIF is intended to eliminate discrimination against foreign banks and to create a more consistent banking environment throughout the region. The integration enables a greater access for ASEAN banking industry. An improvement of access can result the efficiency and the increase of economic growth with lower cost of capital. The ABIF will empower selected banks to penetrate the ASEAN market. The ASEAN Economic Community (AEC) has an impact on the strengthening of capital structure of National Commercial Banks to enter and to expand access to ASEAN market as Qualified ASEAN Banks (QABs). The ABIF will provide a platform for Indonesia that will allow cross border market for Qualified ASEAN Banks (QABs) to expand their business operation into other ASEAN members, which is bind legally by a bilateral agreement. Under the framework agreement, ASEAN Banks can sign reciprocal deals to operate in host country on the same conditions to domestic banks.

ABIF also provides the development for capacity building program and market access gap-reduction. At first, the ABIF aims to achieve a more integrated banking market. It is pioneered by the QABs. The qualification of QAB must be agreed bilaterally between countries. The ASEAN Banks will need to meet for reciprocal access. The ABIF also creates a regional access for well-capitalized and well-managed ASEAN Banks, which will improve their long-term competitiveness and support their expansion across the ASEAN Region. Based on risk management perspective, cross border operation requires equal ASEAN regulatory supervision and regulation for QABs to prevent cross border financial contagion effect from domestic banking crisis in any individual ASEAN state. ${ }^{12}$ The ABIF is a framework to facilitate the entry and operation of Qualified ASEAN Banks (QABs) in other ASEAN members to promote equal access and treatment among ASEAN banks and to facilitate the expansion of intra-regional trade. The QABs are high quality banks that meet specific qualifications including the prudential requirements of host countries. Bank Indonesia (BI) finally agreed on the general criteria of banks that fall into the categories of qualified ASEAN Banks to expand in the region. The criteria include (1) well managed, (2) having sufficient capital, (3) gaining a recommendation from the authority, (4) meeting the Basel provisions, and (5) considered as important banks in the country of origin. The most important point is that the banks are advanced and have good prudential.

Under the ABIF, banks will have greater role to facilitate cross border trade and investment in the ASEAN region. Indonesian QABs will enjoy similar treatment to domestic banks of other states. In this regard, Indonesian banks must anticipate the ABIF by strengthening their capital, human resource quality, well management, the banking regulation reforms, and efficiency to be able to compete at regional or even in global levels.

12 Rajiv Biswas, "ASEAN Banking accord 'a Key Step towards Economic Integration”, http://www.dw.com/en/ asean-banking-accord-a-key-step-towards-economic-integration/a-18333763, accessed on October 2017. 


\section{The Weaknesses of Establishing a Framework for Cross-Border Regulation}

The ABIF also gives challenges to build a cross border regulatory framework without coincided the national prerogatives. The international standards have emerged over the years in response to cross-border management issues. However, the international standards sometimes do not bind the involved parties and it cannot override national laws. On the other hand, the national law and national policy objectives bind the regulators. The recognition becomes difficult when various countries are at different stages of development. ${ }^{13}$ The ASEAN 5 (Indonesia, Malaysia, Singapore, Philippines, and Thailand) and BCLMV (Brunei Darussalam, Cambodia, Laos, Myanmar, and Vietnam) represents two major economically diverse groups of ASEAN. Indonesia is an open and relatively liberalized economy, which could be affected by financial crisis. To keep survive, Indonesia needs to develop its economy and to reform financial commitments that restricted Banks and intermediation process, to improve the financial sector (bank) competitiveness, and to enhance access of finance for all public. The ABIF supposedly does not only integrate for the ease of trade and investment but also have to increase equality across the region. Nevertheless, ASEAN members are at different levels of economic and financial development. Subsequently, it will increase the competition and might be reinforce inequality between ASEAN members.

The ABIF have to prepare to learn from mistakes and to avoid the same risks as the European Union had. Another problem is about various financial regulations across ASEAN members. Various levels of deposit insurance will hinder the process of banking integration and will stop QABs from competing.

\section{E. The Development of Indonesian Banking Regulation}

The development of international cooperation forums for Financial Services, including Banks, happens in ASEAN, Bank for International Settlements (BIS), Basel Committee on Banking Supervision, International Monetary Fund (IMF), and the G20. They give impacts to the structure of national banking policy. The direction of commercial banks policy focuses on the improvement of bank resilience and competitiveness, as well as financial inclusion for market expansion and promoting development. Therefore, the authority directs Indonesian Banking to strengthen the capital and to implement international standards based on Basel III. ${ }^{14}$ According to Basel III's Framework on the "Global Regulatory Framework for More Resilient Banks and Banking System", the regulatory substances are as follows. ${ }^{15}$

13 Michelle Dy, "The Challenges to Cross Border Financial Regulation in the Financial Crisis Era", paper presented on Proceedings of The Annual Conference of the Journal of Financial Regulation: Integration and Interconnectedness in Global Finance, Hongkong, 2016.

14 Indonesia Financial Services Authority (Otoritas Jasa Keuangan), Op.cit., p. 29.

15 Bassel III is an internationally agreed set of measures developed by the Basel Committee on Banking Supervision which is the primary global standard setter for the prudential regulation of banks and provides a forum for regular cooperation on banking supervisory matters. 
Framework Concerning Reciprocity and Gap-Reduction Principles

\section{a. Strengthening the Global Capital Framework}

1. The improvement of quality, consistency, and capital transparency

2. The development of risk coverage

3. The requirement of additional risk-based capital with leverage ratios

4. the reduce of procyclical and increase countercyclical buffer

b. Addressing Systemic Risk and Interconnectedness of the financial institutions. Introduction of Liquidity Standards.

1. Liquidity Coverage Ratio (LCR)

2. Net Stable Funding Ratio (NSFR)

3. Monitoring Tools

Basel Committee on Banking Supervision served to reform Basel II into Basel III which is fundamental to strengthen the capital and liquidity standards to increase the resilience of the banking sector to the crisis. The ability of the banking sector to cope the shock that occur due to financial and economic pressures is expected to reduce the risk from the financial sector that may thrive the national economy.

Indonesia has planned to implement Basel III in early 2019. Banks are expected to conduct its business activities carefully and do not pose a high risk to avoid the financial crisis that may occur in the future. To implement international standards, the authority will prioritize national interests. The regulator is facilitated in monitoring the implementation of Basel III framework. It will help to reduce the difficulty in calculations of banks' risk, weighted assets, and will enable the improvements of comparability and transparency aspects.

The world economy faced a collapse of global economic stability that affected many countries with financial crisis at the end of 2007. It also gave impacts to the Indonesian economy as reflected by the turmoil on the capital market and the money market. The crisis on the financial sector had depressed exchange rates, caused volatility in the price of Government Securities and the risk of non-performing loans. The Bank Indonesia and OJK issued regulations to anticipate the development of the global economy. In the framework of Indonesian banking development (RP2I) 20152019, the OJK issued several key banking policies aimed at strengthening integrated supervision, setting up risk management, and strengthening the capacity of the National Financial Services Industry as follows. ${ }^{16}$

1. Provisions on conglomerate liquidity risk management, conglomerate capital management and intra group transaction exposures to complement capital adequacy arrangements, risk management, and governance of financial agglomeration that have been issued. Currently, the resilience and endurance of the financial services is strongly influenced by the condition of conglomerates, which control three-quarters of the financial market share in Indonesia.

2. The Implementation of Liquidity Coverage Ratio (LCR) is good and effective to

16 Indonesia Financial Services Authority (Otoritas Jasa Keuangan), "Indonesia Banking Booklet 2017”, Banking Licensing and Information Departement, Vol. 4, 2017, p. 53. 
monitor the liquidity of the banking to become more accurate and supervisory measures to be more appropriate. In addition, the OJK issues the Net Stable Funding Ratio (NSFR) provisions for commercial banks as set forth in the Regulation of OJK Number 50/POJK.03/2017, which will be applied to the banks in Book 3, Book 4, and Foreign banks. In order to create a sound banking system capable of developing and competing nationally and internationally, banks need to manage liquidity to comply with the precautionary principle. Therefore, it is necessary to maintain a stable funding profile based on the composition of assets and administrative account transactions to comply with international standards -in this case, the framework of Basel III. Based on the Regulation of OJK number 50/POJK.03/2017, the net stable funding ratio (NSFR) is a comparison between available stable funding (ASF) and required stable funding (RSF). The bank capital requires a standard calculation of liquidity ratios related to funding sources to measure the Minimum Level of Stable Funding. The Banks must maintain and adjust to the applicable international standards of Basel III. The designation of NSFR aims to ensure that banks maintain stable funding tailored to the composition of assets and administrative accounts. the banks are expected to reduce the risk of liquidity related to funding sources for a longer period of time. Thus, banks need to improve funding stability by limiting the excessive reliance on short-term funding sources derived from corporations. Therefore, commercial banks are required to meet the Net Stable Funding Ratio.

3. The Law Number 9 of 2016 concerning Prevention and Mitigation of Financial System Crisis requires OJK to issue several related regulations. They are the Regulation of OJK Number 14/POJK.03/2017 (concerning provision of the Action Plan for systemic banks); the Regulation of OJK Number 15/POJK.03/2017 (concerning the Stipulation of the Status and Follow Up of Commercial Bank Supervision); the Regulation of OJK Number 16/POJK.03/2017 (concerning Intermediary Banks); and the Regulation of OJK Number 43/POJK.03/2017 (concerning Follow-up Implementation of Bank Supervision). From the above three regulations, the OJK set out the rules of systemic bank obligations to prepare a plan to prevent and to overcome financial problems that may occur in systemic Banks by preparing a plan of action (recovery plan). The action plan is an effort to solve bank's financial problems that should be started since the bank in a normal condition with significant problems. With the existence of these three regulations, systemic banks must try to solve financial problems by independent effort or bailing in term. The concept of bail means the handling of liquidity and solvency problems by using relevant resources that come from the shareholders and creditors. Other options cover the results of asset management and liabilities of banks and the contribution of the banking industry. This is in line with the recommendations of the Financial Stability Board. Bail, in this approach, enables the troubled banks not to burden the state. 
The entry of foreign banks to Indonesia in one of the consequences of global banking should be taken seriously by the regulator, in this case Bank Indonesia and the OJK. These foreign banks have certainty brought the best system and business strategy that they have implemented for so long in their country. Therefore, the national banks and the government banks should be more competitive to win the industry.

Banking regulation, and most especially prudential regulation, tends to be particularly rules-based and prescriptive. This seems to be a common characteristic of financial regulation in general because it is traditionally perceived in terms of command and control. A prescriptive approach focuses on specific steps required for the accomplishment of a determinant regulatory objective.

Banking regulations, especially related to prudence, are regulatory and compelling provisions. This has become a characteristic of financial regulations, which contains command and control. A prescriptive approach focuses on the specific steps needed to fulfill goals based on the rules that dictate how and what to do by the company. The compelling rules are the result of interactions between the interests of regulators who are looking for standards in order to easily supervise and enforce the rules and, on the other hand, the interests of the entity regulated to look for standards to be easily obeyed.

OJK motivates financial services industry to increase its contribution in the national economic growth and to enhance competitiveness, particularly in facing the ASEAN Economic Community (AEC). The regulatory authorities are responsible for overseeing and supervising financial services institution, including banks in Indonesia. They are Bank Indonesia (BI) for macro prudential policy regarding monetary policy and Indonesia Financial Services Authority (OJK) for micro prudential policy. To carry out its responsibilities, OJK coordinates with The Financial Transaction Reporting and Analysis Centre (PPATK) regarding large and suspicious transactions and The Indonesia Deposit Insurance Corporation (LPS) regarding the guarantee of bank customer deposit and the management of failing banks.

Indonesia has planned to reform the banking law system to anticipate mediumand long-term banking development. Legal challenges in bank supervision include the effective date of ASEAN Economic Community (AEC), the uncertainties of global economy, the rising of environmental issues and global economic gap, and the end of implementation period for Indonesian Banking Architecture (API) in 2013. The following are the OJK focus for mid-term development banking industry. ${ }^{17}$

1. Continuing the rapid growth of banking reflected in the assets, financing, public fund collection with due regard to banking portfolio shifting to fulfill the funding of priority economic sector and to give a strong multiplier effect.

2. Improving banking ability in outreaching the communities through inclusive financial initiative and branchless banking.

17 See Indonesia Financial Services Authority (Otoritas Jasa Keuangan), “Indonesia Banking Booklet 2016”, Banking Licensing and Information Department, 2016. 
3. Strengthening the banking risk management and Good Corporate Governance (GCG) implementation to support portfolio shifting process and expansion of service, as well as to improve bank's resilience to critical conditions.

4. Improving the role of banks in the funding of environmental-friendly business sectors as a part of the implementation of sustainable Finance Roadmap (RKB).

5. Accelerating the arrangement of national banking industry structure to form strong and sound national banks to be able to compete in ASEAN level. Small capital banks dominate the number of banks with less than Rp5 Trillion of capital. This condition is less ideal to support economic growth, which requires adequate capitals support from banks. The AEC has brought a consequence that small capital banks will also face challenges of competition in the ASEAN region. Each bank is also encouraged to be competitive and to improve its service quality and operational efficiency.

In 2016, the OJK launched a master plan for financial services sector for 20152019. To prepare the need of current economic development, the OJK will focus on achieving the following three main targets. ${ }^{18}$

1. Optimizing the role of the financial services sector and supporting the acceleration of economic growth.

2. Maintaining financial system stability as the platform for sustainable development.

3. Financial services sector will be directed to motivate the realization of public financial self-reliance and to support the efforts to enhance equality in development.

Based on macro prudential policy, the G20's commit on global financial sector reform. It includes the improvement of banks' capital and liquidity standards, addressing systemically important financial institution (SIFIs), expanding and refining the regulatory perimeter, improving the OTC and commodity Derivatives Markets, developing macro prudential frameworks and tools, strengthening and converging accounting standards, strengthening adherence to international supervisory and regulatory standards, etc.

\section{The Supervision of ABIF Implementation Process by Indonesian Financial Services}

ABIF is an ASEAN initiative to create integration framework to accelerate banking integration through market access and operational flexibility among ASEAN members by still observing the fulfillment of prudential requirement applicable in each ASEAN member. The process of ABIF uses Qualified ASEAN Banks (QABs) as the banks that are qualified under certain general conditions agreed by ASEAN members. the participants of ABIF should meet a set of criteria to be stated as QABs. Indonesia is a member of G-20 and other international forums, such as Financial Stability Board (FSB), Basel Committee on Banking Supervision (BCBS), etc. Indonesia is committed to adopt recommendations made by those forums. The shifting of

18 Ibid. 
supervision function from Bank Indonesia to the OJK require the OJK to adopt the recommendations. In the process of adopting the recommendations, OJK will adjust them with the condition and development of domestic banking.

The bank supervisory authority focuses on capital to implement prudential banking principle. The government focuses on the strengthening the Basel II framework and implementing the Basel III framework. The government needs to reform the banking law since 2008. It is necessary to maintaining the health of banks and resilience of national and global financial systems. The meeting of G20 states in 2012 requires all states to implement the agenda of Basel II and to start implementing the Basel III in 2013. The role of Bank capital and liquidity is very important. The G20 states are required to comply with the Basel Committee on Banking Supervision (BCBS) recommendations on international banking standards. By the implementation of international banking standard, Indonesia is expected to create a healthy banking industry.

Based on Article 5 of the Law Number 21 of 2011 concerning Financial Services Authority (OJK), the OJK is mandated to organize an integrated system of regulation and supervision toward the entire activities of financial services sector. The OJK sees Indonesia ready to implement ABIF as a part of commitment to ASEAN Economic Community. The need of national banks to expand abroad will be guarded by the OJK through the ABIF that has been agreed. in the negotiations of a bilateral agreement between Indonesia and the banking authorities or other ASEAN members, the OJK will serve as the Indonesian representation. the bilateral agreements Indonesia enable to send selected banks as Qualified ASEAN Banks.

Indonesia has signed Heads of Agreement (HoA) involving OJK and Bank Negara Malaysia (BNM). This is a manifestation of Indonesia's desire to ensure workability and mutual benefits for both parties. The process of granting equal treatment to all banks is the duty of financial services authority. The ABIF has a very fundamental principles: the principles of reciprocity and gap reduction. the principle of reciprocity is to gain the equality of access and treatment for $Q A B s$, an equal access means to promote active penetration on regional banking market by ASEAN banks. The ASEAN members should agree the conditions that ASEAN-based banks must qualify as QABs. Equal treatment allows ASEAN-based banks to participate actively in domestic banking markets.

According to the schedule of specific commitment of banking sector between Indonesia and Malaysia, ${ }^{19}$ on July 2017, PT. Bank Mandiri (Persero) has met the criteria of Qualified ASEAN Bank and will establish a branch office in Malaysia by the end of 2017. Subsequently, PT. Bank Rakyat Indonesia (BRI) (Persero) is considered to establish in Malaysia. The Bank Mandiri will be the first QAB in Malaysia. The principle of reciprocity becomes an important element in bilateral agreement to gain the equality of access, treatment, and environment for QABs.

19 See ASEAN Economic Community Blueprint 2025. 
The prudential requirements must be harmonized to prevent potential conflict among national supervisors.

The ABIF is a positive enhancement to encourage Indonesian Banks. As a licensed bank (QAB), Bank Mandiri will operate in Kuala Lumpur to support business activities. To open a branch in Malaysia, Bank Mandiri is preparing capital for approximately 300 Million Malaysian Ringgit or equivalent to 933.97 Billion Rupiah (Exchange Rate: Rp3.113 = RM1 ). ${ }^{20}$ Referring to a schedule of commitment, the bilateral agreement between Indonesia and Malaysia covers several things, such as national treatment will for branching and off site ATMs, access to networking with e-payment system that includes ATM networks, internet banking, mobile banking, and other electronic channels. Market access has been agreed upon designating existing Malaysian Banks in Indonesia as (two) QABs may establish a presence as a commercial bank or both. The third Malaysian QAB shall be established after three Indonesian QABs in Malaysia fully operate. ${ }^{21}$

The entrance of Bank Mandiri to Malaysia provides an opportunity to enhance regional integration in payment system between Indonesia and Malaysia. The collaboration between ATM switches in Malaysia. Malaysian Electronic Payment System (MEPS) and Indonesia (ATM Bersama) to facilitate cross-border cash withdrawals can be enhanced to facilitate cross border remittances and be extended to facilitate retail payment card transactions. ATM in Malaysia and Indonesia will be linked seamlessly, thus reducing cost, enhancing safety, and expanding outreach. Indonesian banks will be treated equally with local Malaysian banks. Consequently, this is a milestone for both countries and represents the realization of a vision of the $A B I F$, allowing $Q A B s$ to operate freely in the host country.

\section{Conclusion}

ASEAN still faces challenges of a sizeable gap between ASEAN members. The ABIF has been able to reap full benefit of the integration. The ABIF is positive enhancements to encourage Indonesian Banks to do better in the competition and to expand their operational network in ASEAN market. The framework requires the government to harmonize the regulation for the Banking Integration. Based on a schedule of commitment, PT. Bank Mandiri (Persero) had announced that they have met the criteria of Qualified ASEAN Bank; and will establish a branch office in Malaysia by the end of 2017.

Dusep Malik, “Akhir 2017 Bank Mandiri akan dirikan Bank Baru di Malaysia”, https://www.viva.co.id/berita/ bisnis/932514-akhir-2017-mandiri-dirikan-bank-baru-di-malaysia-nbsp, accessed on October 2017.

21 Schedule of Spesific Services Commitments, "Protocol to Implement Sixth Package of Commitment on Financial Services Under The ASEAN Framework Agreement on Services", http://asean.org/storage/2016/12/ Consolidated-AFAS-6-SOCs-with-ABIF-Commitments.pdf, accessed on October 2017. 


\section{References}

\section{Books}

Cutter, Robert and Thomas Ulen, Law \& Economics, Berkeley Law Book, Addison Wesley, New York, 2000.

Indonesia Financial Services Authority (Otoritas Jasa Keuangan Indonesia), Indonesian Financial Services Sector Master Plan 2015-2019: Fostering Growth and Addressing Challenges in The Financial Services Sector, Today and Tomorrow, Indonesia Financial Service Authority, Jakarta, 2016.

Indonesian Financial Services Authority (Otoritas Jasa Keuangan Indonesia), Indonesian Financial Services Sector Master Plan 2015-2019: Spur Growth and Respond to Financial Services Sector Challenges Now and Later, Indonesia Financial Services Authority, Jakarta, 2016,

Yung Chul, Park, The Road to ASEAN Financial Integration: A Combined Study on Assessing the Financial Landscape and Formulating Milestone for Monetary and Financial Integration in ASEAN, ASEAN Development Bank, Philippines, 2013.

\section{Other Documents}

ASEAN, "ASEAN Economic Community Blueprint 2025", The ASEAN Secretariat, Jakarta, 2015.

Biswas, Rajiv, "ASEAN Banking accord 'a Key Step towards Economic Integration", http://www.dw.com/en/asean-banking-accord-a-key-step-towards-economicintegration/a-18333763.

Chen, Vivien (et.al), "Cross Border Cooperation in Bank Resolution: A Framework For ASIA", Singapore Journal of Legal Studies, 2016.

Dusep Malik, “Akhir 2017 Bank Mandiri akan dirikan Bank Baru di Malaysia”, https:// www.viva.co.id/berita/bisnis/932514-akhir-2017-mandiri-dirikan-bank-barudi-malaysia-nbsp.

Dy, Michelle, "The Challenges to Cross Border Financial Regulation in the Financial Crisis Era", Proceedings of The Annual Conference of the Journal of Financial Regulation: Integration and Interconnectedness in Global Finance, Hongkong, 2016.

Hsieh, Pasha L., "Examining the Liberalization of ASEAN's Legal Services Market: Challenges and Reforms", http://www.cnplaw.com/en/interlaw/files/ submission Hsieh.pdf.

Indonesia Financial Services Authority (Otoritas Jasa Keuangan), “Indonesia Banking Booklet 2016", Banking Licensing and Information Department, March 2016.

Indonesia Financial Services Authority (Otoritas Jasa Keuangan), "Indonesia Banking Booklet 2017", Banking Licensing and Information Department, Vol. 4, 2017.

Mahendrawathi ER (et.al), "Readiness of Indonesian Companies for ASEAN Economic Community (AEC)-Preliminary Findings from Automotive and Garment Industry", Proceeding of 2014 International Conference on Industrial Engineering and Operations Management, Bali-Indonesia, 7-9 January 2014. 
Maria Monica Wihardja, "Financial Integration Challenges in ASEAN Beyond 2015", Economic Research Institute for ASEAN and East Asia, 2014.

Schedule of Spesific Services Commitments, "Protocol to Implement Sixth Package of Commitment on Financial Services Under the ASEAN Framework Agreement on Services", http://asean.org/storage/2016/12/Consolidated-AFAS-6-SOCswith-ABIF-Commitments.pdf.

Suparman Zen Kemu, "The Readiness of Indonesia's Banks Facing ASEAN Community (AEC)", Information Management and Business Review (IMBR) Journal, Vol. 9., Issue 3.

Yati Kurniati, "ASEAN Banking Integration Framework; Advance and Challenge in Regional Integration Jointly Organized by Hitosubashi University and the IMF Regional Offices for ASIA and the Pacific", Macroprudential Policy Department of Bank Indonesia, 2016.

\section{Legal Documents}

Law Number 7 of 1992 as amended by the Law Number 10 of 1998 on Banking.

Regulation of OJK Number 50/POJK.03/2017 on the Obligation of Net Stable Funding Ratio. 